\section{Dei leprasjuke - eit trugsmål mot framsteget?}

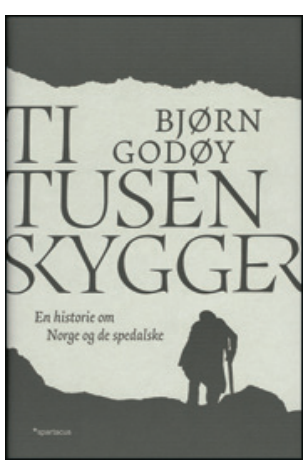

\author{
Bjørn Godøy
}

\section{Ti tusen skygger}

En historie om Norge og de spedalske. 257 s, ill. Oslo: Spartacus Forlag. Pris NOK 369 ISBN 978-82-430-0612-6
Eg hadde minst fire gode grunnar til å kaste meg over historikaren Bjørn Godøy si forteljing om dei leprasjuke og kampen mot sjukdommen i Noreg - ein sjukdom som slo hardast til blant kystfolket på Vestlandet frå 1830-åra og frametter: Eg trødde mine barneskor i ei kystbygd på Sunnmøre. Eg arbeider i Pleiestiftelsen no. $1 \mathrm{i}$ Bergen, som var ein av dei viktigaste institusjonane i oppbevaringa av dei sjuke, etablert i 1857. Eg har kontor så å seie vegg i vegg med laboratoriet (i dag minnerom) til den legendariske Gerhard Armauer Hansen (1841-1912), han som identifiserte leprabasillen i 1873. Eg er, som medisinhistorikar, kollega med leprahistorikarane/-forskarane i Bergen, dvs. forskarar som Godøy i stor grad byggjer på og har søkt råd hos. La det straks vere sagt, Godøy har skrive ei særs leseverdig

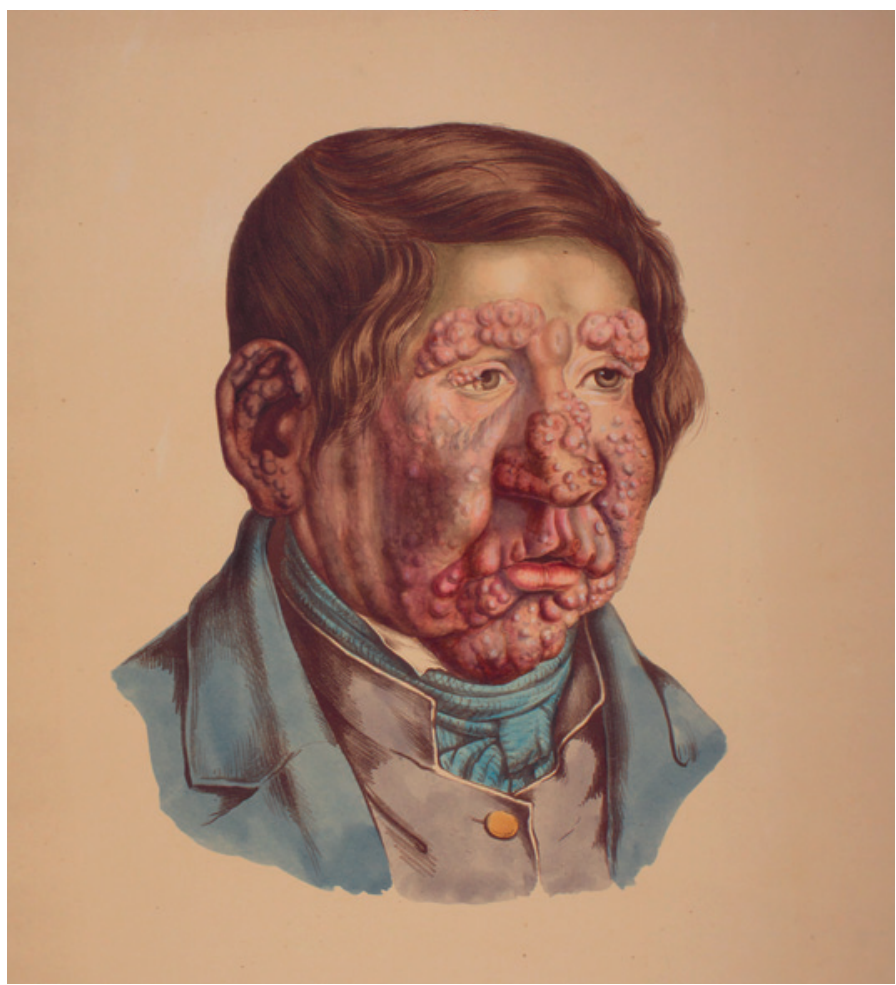

«En 13 Aar gammel Dreng, hos hvem Knuderne ere fuldkommen udviklede, de ere confluerede paa flere Steder, og mange have begyndt at ramollere. Öienbrynere ere affaldne. Han blev spedalsk i sit 6te Aar.» J.L. Lostings lepraatlas/Bymuseet i Bergen - Lepramuseet St. Jørgens Hospital bok, så vel i innhald som i språkleg framtoning. Og sjølv for ein som er relativt velinformert om denne historia, har det vore mykje å lære.

Som god historikar tar Godøy mål av seg til å gje ei heilskapleg forståing av lepraen. Han går inn på epidemiologiske særtrekk, etiologi, symptomatologi, terapi, førebygging, helsepolitikk, institusjonsbygging, pasienterfaringar og kulturell forståing. Han trekkjer linjene attende til bibelsk tid, fortel at ein gjennom dei siste 200 åra har oversikt over at om lag 10000 nordmenn vart råka, og at den siste pasienten døydde så seint som i 2002. Det galdt ei kvinne frå Øygarden utanfor Bergen som hadde såpass svake symptom at ho arbeidde som sekretær for overlegen ved Attføringsinstituttet, som frå 1973 var plassert i Pleiestiftelsen. Framfor alt diskuterer

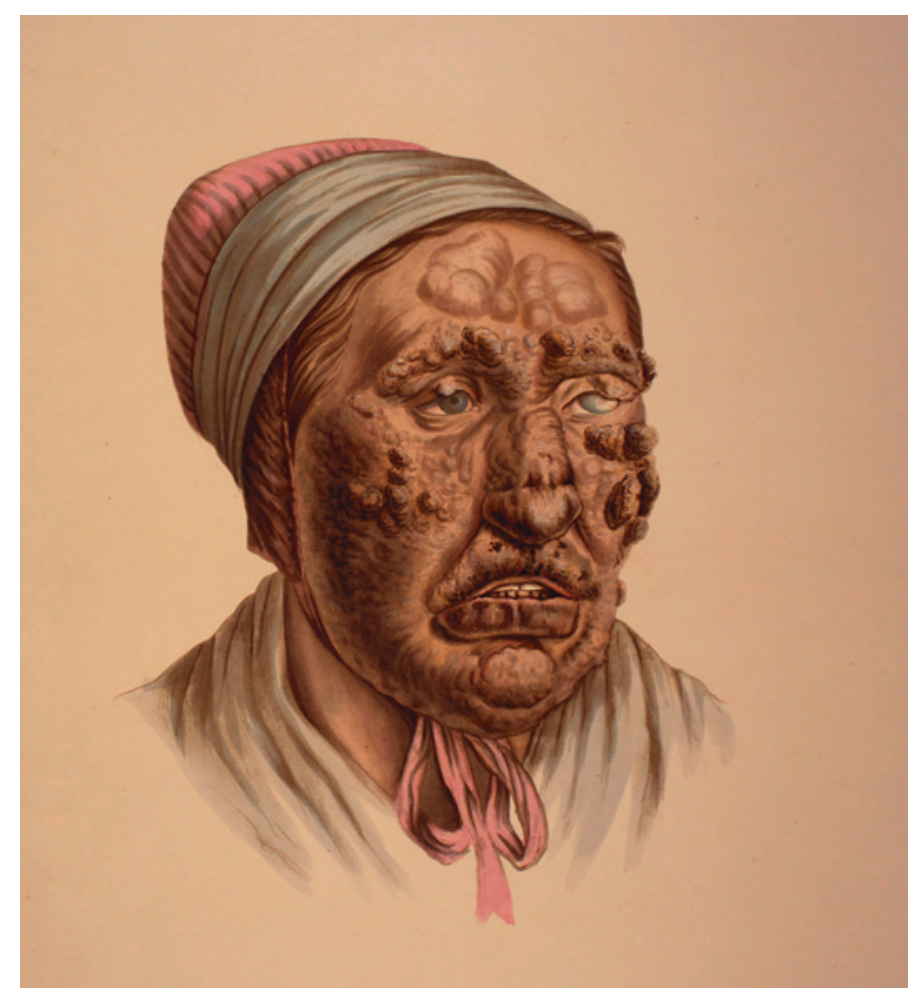

«En Pige, 28 Aargammel, hos hvem Knuderne ere confluerede, og bedækkede med tykke graabrune Skorper, der kunne opnaae indtil 2 Tommers Höide. Borttages disse Skorper, frembyde Knuderne et ulcereret Udseende. Saavel paa Overfladen, som dybere ind i Knudemassen leve Millioner af en Acaride, som vi antage for acarus scabiei. Skorperne bestaae næsten udelukkende af Legemer af det döde Dyr. De enkelte Knuder, der ikke ere bedækkede med Skorper, have, ligesom den endnu sunde Hud, en skiden graabrun Farve.» J.L. Lostings lepraatlas/Bymuseet i Bergen - Lepramuseet St. Jørgens Hospital 
Godøy «hanekampen» mellom legane om kven som forvalta sanninga. Var sjukdommen arveleg, var han smittsam, skuldast han «fejlagtig blodblanding», miasmar, bakteriar, dårleg hygiene, elendig kosthald, frost, kulde, fuktig klima? Teoriane florerte. Ikkje minst interessant er boka fordi kampen mot sjukdommen fortel om framveksten av det moderne Noreg, og om vitskapens plass og verknad i denne prosessen. Det «bakteriologiske gjennombrotet» i 1870- og 1880-åra bidrog til å endre folk sine vanar, samværsformer og sjukdomsforståing, til å gjere livet vanskelegare for dei som bar på ein smittsam sjukdom, og til å endre legane sine formaningar til folket - og ikkje minst til å endre pasientane sitt eige sjølvbilete.

Kjeldematerialet som Godøy nyttar, er omfattande og tidlegare til dels ubrukt. Ikkje minst har det vore interessant å få innsyn i den private brevvekslinga mellom forskarpioneren og lepralegen Daniel Cornelius Danielssen (1815-1894) og hudlegen Carl Wilhelm Boeck (1808-1875). Dei diskuterer smitteteoriar, kjem med synspunkt på «håplause» kollegaer og fortel om forskingsresultat og arbeid, om nederlag og kriser. Men også årsprotokollane frå den som til ei kvar tid var overlege for dei leprasjuke, og frå dei tre store pleiestiftingane - No. 1 i Bergen, Reknes ved Molde og Reitgjerdet ved Trondheim - gjev spanande og ny informasjon. Samla er dei sterke vitnemål om dei vilkåra og dei kjenslene som var knytte til «spillsykja». Kanskje framfor alt skamma, skamma over den vansira kroppen, over den uuthaldelege stanken, over å vere ei bør for familien, skamma over å vise seg fram for øvrigheita, skamma andsynes Gud - var ikkje sjukdom eit teikn på synd? Samstundes var tanken på livet $\mathrm{i}$ det hinsidige den einaste trøysta mange hadde. Pasientane sine mentale lidingar var enorme. Så var det dei fysiske plagene, dei grufulle smertene, armar, bein, tunger og auger som vart deformerte og ubrukelege, og for ikkje å snakke om seigpininga. Dei leprasjuke kunne gå $i$ årevis med lidingane sine og vere innesperra nesten like lenge. Godt då å høyre at dei frå tid til anna klarte å heve si eiga røyst og sette foten ned mot urimelege tilstandar og krav i institusjonane.

Kanskje var lepraen den verste sjukdommen eit menneske kunne få? Det er vanskeleg å sette seg til doms over fortidas lidingar. Det var så mykje som var ille i hundreåra før oss, før antibiotika og sulfapreparat, før vår tids kirurgiske tryllekunstnarar, før vår tids økonomiske velstand. Kanskje var ratesjuka (radesygen) like ille? Ein hudsjukdom som gong på gong vert sagt å vere ei syfilitisk liding/ tertiær syfilis (også av Godøy med referanse til Anne Kveim Lie). Men medisinhistorikaren Anne Kveim Lie seier noko anna. Under arbeidet med den store avhandlinga om ratesjuka (rate/rade tyder stygg) kom ho fram til eit meir nyansert bilete: Sjuka kunne vere eit samleomgrep for fleire sjukdommar - skabb, skjørbuk, tertiær syfilis, tuberkulose, lepra, ikkje-veneriske treponematoser m.v. Så seint som i 1993 vart han diagnostisert som ein soppsjukdom. I ei tid utan våre teknisk-kjemiske diagnosemetodar kan vi ikkje sjå bort ifrå korkje det eine eller det andre. Vi har ikkje eingong bilete eller teikningar (slik vi har i rikt monn av lepraen) av denne svært utbreidde lidinga, som herja i siste helvta av 1700-talet og dei fyrste tiåra av 1800-talet (1).

Ei bokmelding skal også ha nokre kritiske merknadar. Fyrst til språket, som eg alt har rosa som godt og flytande. Men stundom vert forfattaren riven med av sin eigen formuleringskunst. Det vert vel melodramatisk når han skriv: «Men naturen regjerte ikke bare utenfor de laftede tømmerveggene. Den strakk sine krefter også innendørs og inn bak hud og hår, gjennom kjøttet og like inn til marg og ben» (s. 13). Ei anna, og kanskje «alvorlegare» innvending, er bruken og tolkinga av legane sine rapportar og medisinalmeldingar. Godøy refererer ofte til kor elendig det sto til på Vestlandet, slik legane såg det, med Sunnfjord som det elendigaste og mest underutvikla av alt i Noregs land. På den andre sida vart Austlandet framheva som sivilisasjonens fyrtårn. Her meiner eg at han

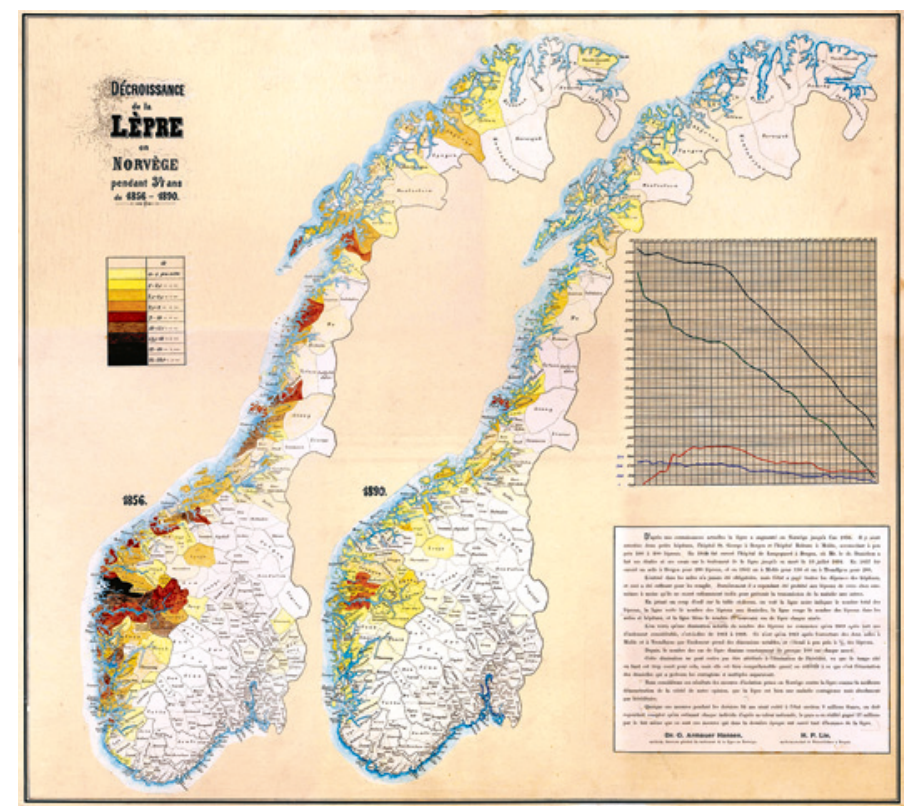

Kart over den geografiske fordelinga av lepratilfelle i Noreg i 1856 og 1890. Bymuseet i Bergen - Lepramuseet St. Jørgens Hospital

tek feil. Gå inn i medisinalmeldingar frå kvar som helst på 1800talet, sjå på retorikken, ordbruken, omgrepa og skildringane av «folket». Dei er til forveksling like same kva plass legane melde ifrå - om det er frå arbeidarstrøka i Bergen eller Kristiania, frå bygdene i Finnmark, frå fjellbygdene i Trøndelag eller på Austlandet osb. Vi les ofte og mykje om marginale livsvilkår, om eit einsidig og skadeleg kosthald, om skit og lort, om usselt barnestell, om helseskadelege bustadhus, om sedløyse og drukkenskap og om misbruk av kaffi (!) - kort og godt om eit ukunnig, uviljug og «forvillet» folkeferd. Og mellom linjene les vi om ein embetsstand som i eigne auge kjempa for sivilisasjon og framsteg, og som verken kunne eller ville ta innover seg og akseptere folket sine økonomiske vilkår, tradisjonar og kultur $(2,3)$. Det er mest som ein «høyrer piskesnerten over ein meir eller mindre uvitande og i alle fall tungnem allmuge», som historikaren Jostein Nerbøvik formulerte det (4). Eit siste punkt ein kan diskutere, er i kva grad vi i dag kan sette oss til doms over dei tiltaka som vart nytta andsynes dei leprasjuke. Dei var strenge og til dels umenneskelege, seier Godøy med rette, men dei var stort sett betre enn i andre land. Det siste var no kjekt å høyre, men spørsmålet er korleis vi i vår tid vil reagere andsynes alvorleg smittsam sjukdom dersom vi ikkje har hjelperådene. Ei påminning kan vere behandlinga av dei aidssjuke i 1980åra, og for ikkje å snakke om hysteriet $\mathrm{i}$ vestlege land rundt ebolaepidemien. Men attende til Noreg og Ti tusen skygger: les og lær. Dette er medisinsk historie på sitt beste.

\section{Aina Schiøtz}

Professor, Institutt for global helse og samfunnsmedisin Universitetet i Bergen

\footnotetext{
Litteratur

. Lie AK. Radesykens tilblivelse. Historien om en sykdom. Doktoravhandling. Oslo: Universitetet i Oslo, 2008

2. Schiøtz A. Distriktslegen - en kulturell overgriper? Kulturmøter, modernisering og makt. Heimen 2004; nr. 2: $163-78$

3. Schiøtz A. Medisinalberetningene som historie og kilde. Arkivmagasinet. Informasjon fra Riksarkivaren 2003; 17/3: 17-25

Nerbøvik J. Heil og rein er heile stasen. Sunnmørsposten 11.10.2003.
} 